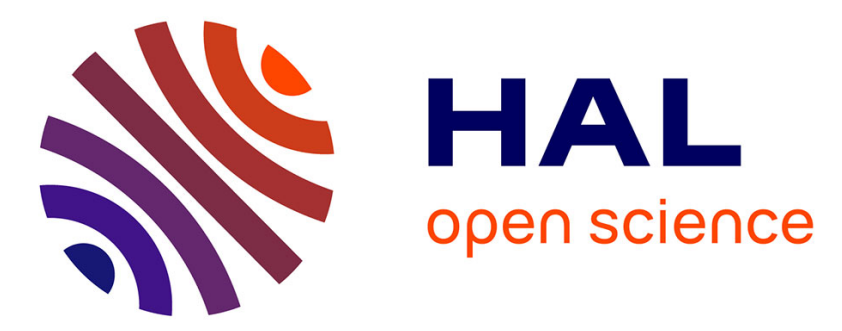

\title{
Review of the U.S. department of energy's solar thermal program
}

G.W. Braun, R.B. Edelstein

\section{To cite this version:}

G.W. Braun, R.B. Edelstein. Review of the U.S. department of energy's solar thermal program. Revue de Physique Appliquée, 1980, 15 (7), pp.1219-1228. 10.1051/rphysap:019800015070121900 . jpa-00244844

\section{HAL Id: jpa-00244844 https://hal.science/jpa-00244844}

Submitted on 1 Jan 1980

HAL is a multi-disciplinary open access archive for the deposit and dissemination of scientific research documents, whether they are published or not. The documents may come from teaching and research institutions in France or abroad, or from public or private research centers.
L'archive ouverte pluridisciplinaire HAL, est destinée au dépôt et à la diffusion de documents scientifiques de niveau recherche, publiés ou non, émanant des établissements d'enseignement et de recherche français ou étrangers, des laboratoires publics ou privés. 


\title{
Review of the U.S. department of energy's solar thermal program
}

\author{
G. W. Braun $(*)$ \\ Chief, Solar Thermal Branch U.S. Department of Energy \\ and R. B. Edelstein $(* *)$ \\ Deputy Project Manager PRC Energy Analysis Company \\ (Reçu le 8 octobré 1979, révisé le 17 mars 1980, accepté le $1^{\text {er }}$ avril 1980)
}

\begin{abstract}
Résumé. - Le Programme de l'Energie Solaire Thermique du Département de l'Energie des Etats-Unis comprend des entreprises échelonnées de recherche et de développement qui assistent l'industrie américaine dans la préparation technique et financière des systèmes de capteurs concentrateurs à moyenne et à haute température. La réalisation commerciale subséquente sera basée sur la recherche et le développement des composantes et des sous-systèmes, et des essais d'applications à petite échelle. Actuellement, le programme entre dans une phase visant à l'implantation d'une première génération de projets expérimentaux et d'installations d'essais en parallèle avec le développement d'une deuxième génération de projets de concentrateur, de systèmes à capteurs distribués, et de concepts de systèmes améliorés et/ou de plus haute température.

Trois classes de systèmes ont été identifiées comme ayant le pouvoir de gagner la majeure partie des secteursclefs du marché de l'énergie première aux Etats-Unis. La convenance de ces systèmes aux marchés en question est basée sur leurs caractères optiques uniques (donc, applicabilité géographique différente et capacité de température). Les trois classes principales sont : les récepteurs à concentration linéaire (miroirs cylindro-paraboliques, miroirs hémisphériques); les récepteurs distribués focalisant sur une pointe (réflecteurs paraboloïdes) ; et systèmes de récepteurs centraux. Ces systèmes seront utilisés à produire de l'électricité, à fournir de la chaleur dans les processus industriels au point d'utilisation, à fournir du chauffage et de l'électricité en combinaison pour les besoins industriels, commerciaux et résidentiels, et enfin, conduire à des transformations qui produisent des combustibles liquides et gazeux. Les systèmes de concentrateurs solaires-thermiques offrent un abord qui se plie à tout, qui est praticable, et qui sera bientôt rentable, en réduisant la demande de notre pays de combustibles importés en toutes catégories d'utilisation.
\end{abstract}

\begin{abstract}
The U.S. Department of Energy Solar Thermal Program involves phased research and development activities to assist U.S. industry in establishing the technical and cost readiness of mid and high temperature solar concentrating collector systems. Subsequent commercial implementation of these systems will build on this base of component/subsystem research and development, test facilities and sub-scale applications experiments. The program is now proceeding to a phase involving implementation of first generation designs in field experiments and pilot plants, in parallel with the development of second-generation concentrator and collector array designs and improved and/or higher temperature system concepts.

Three classes of systems have been identified as having the potential to capture major shares of key sectors of the United States primary energy market. The suitability of these systems to the markets in question is based on their unique optical characteristics (hence, different geographic applicability and temperature capability) and modularity (hence, scale of application). The three major classes are linear distributed receivers (e.g., parabolic troughs and hemispherical bowls), point focusing distributed receivers (e.g., parabolic dishes), and central receiver systems. These systems will be used to produce electricity, provide heat at its point of use in industrial processes, provide heat and electricity in combination for industrial, commercial, and residential needs, and, ultimately, drive processes for production of liquid and gaseous fuels (e.g., for the transportation sector). Solar thermal concentrator systems offer a highly versatile, practical, and soon-to-be-economically-feasible approach to reduce our nation's requirements for imported fuels in all major categories of use.
\end{abstract}

(*) Now assistant director, Solar Energy Thermal Systems Division, U.S. Department of Energy.

$\left({ }^{* *}\right)$ Now employed at the Solar Energy Research Institute, Golden, Colorado.
1. Introduction. - The DOE Solar Thermal Program is a key element in support of the President's goal of producing $20 \%$ of the nation's energy from 
solar by the year 2000 . The electric and industrial heat applications of solar thermal concentrator systems are targeted to contribute $3\left(10^{18}\right) \mathrm{J}$ ( 3 quads) of the 18.5 per year, called for in the most recent National Energy Plan. This is about half of the 6 quads per year expected from direct collection concepts, the balance coming from non-concentrating solar thermal systems ( 2 quads per year), and photovoltaics (1 quad per year). Further, it is expected that concentrating collectors will compete strongly in low temperature applications with presently commercial non-concentrating flat plate collectors, while photovoltaic concentrator system designs benefit directly from the technology base developed in the Solar Thermal Program.

The strategy to achieve these goals involves : 1) subsystem development and testing to yield massproducible designs, 2) system technical and cost validation for near-term applications, 3) product improvement and validation for early opportunity markets, 4) advanced subsystem development and testing for major impact in all market sectors, and 5) support of early commercial activity through incentives and other means.

The Solar Thermal Program supports the development of concentrating collector systems for utility, industrial, commercial and residential applications. These systems use mirrors or lenses to concentrate the solar radiation onto a smaller area (receiver) to obtain useful heat at temperatures from $150^{\circ} \mathrm{C}\left(300{ }^{\circ} \mathrm{F}\right)$ to $1650^{\circ} \mathrm{C}\left(3000^{\circ} \mathrm{F}\right)$. This energy is transferred to a working fluid for use directly as process heat or for space heating or cooling, for conversion to mechanical or electrical energy, or for combined use in total energy or cogeneration applications.

There are three generic types of concentrator systems under development. These are the central receivers, typified by the utility pilot plant now under construction near Barstow, California ; linear concentrators such as the parabolic trough irrigation pumping system recently placed in operation near Coolidge, Arizona ; and parabolic dish (paraboloidal) concentrators typified by the industrial total energy system under construction at Shenandoah, Georgia. Hemispherical bowl technology, represented by the test module recently deployed at Crosbyton, Texas, is also funded under the linear systems program.

The technical feasibility of concentrating collector systems was established long ago. August Mouchot constructed and operated several solar-powered steam engines between 1864 and 1878 using a truncated cone reflecting surface. Albert Pifre operated a solarpowered printing press in Paris in 1882 using a paraboloidal reflector. John Ericsson developed and demonstrated solar-powered hot air engines between 1872 and 1883. In 1913 at Meadi, Egypt, Frank Schuman and C. V. Boys constructed a solar power plant for irrigation pumping on the banks of the Nile using parabolic trough collectors $[1,2]$.
These early concentrator systems found no permanent niche in an expanding energy market based on inexpensive and abundant fossil fuels. Today, however, fossil fuel scarcities, uncertainties and price increases have improved the conditions for the commercial acceptance and industrial production of concentrating collector technologies. Acceptance is also aided by improved mass production techniques and new materials not available to the entrepreneurs of the nineteenth century.

The Solar Thermal Program emphasis, then, is on 1) developing technically satisfactory products that are mass producible at the right price and 2) establishing an industrial base and stimulating early penetration of large markets. Technically satisfactory products are those which have demonstrated acceptable durability, reliability and performance characteristics under actual operting conditions.

The right price is a necessary condition imposed by the markets. The 1990 cost goals for collectors are $\$ 75-150 / \mathrm{m}^{2}\left(\$ 7-14 / \mathrm{ft}^{2}\right)$, or $\$ 1000-2000 / \mathrm{kWe}$ for electric applications and $\$ 5-10 / 10^{9} \mathrm{~J}(\$ 5-10 / \mathrm{MBtu})$ for process heat applications. Technically satisfactory systems satisfying these goals will be purchased in sufficient number as to have a major impact on our energy economy before the turn of the century.

It has been estimated that these prices are achievable with production rates on the order of 10000 concentrators (each about $50 \mathrm{~m}^{2}$ ) per year. Accordingly, this is a minimum production level (for each concentrator type) for a self-sustaining production capacity and a viable industrial base. The industrial base necessary to permit early market penetration is rapidly developing, with over one hundred small and large companies actively participating in the Solar Thermal Program. User interest in the utility and industrial sectors is correspondingly high. These sectors account for more than half of our nation's energy supply.

The Solar Thermal Program is structured to provide integrated programs for each of the major concentrator approaches, beginning with component level tests and ending with validation of full systems at a scale appropriate to early opportunity markets. In addition, an advanced technology program provides funding and focus for improvements in concentrator and receiver materials and designs, thermal storage technology, and other advanced subsystem development aimed at broadening the market capture potential of solar thermal systems, once the industrial base is established.

The Fiscal Year (FY) 1980 budget for the Solar Thermal Program is $\$ 121$ million, including $\$ 65.0$ million for the Central Receiver Program (\$50.3 million for system development and applications experiments and $\$ 14.7$ million for technology development), \$34 million for the Distributed Receiver Program (\$13.1 million for line focus systems, \$20.9 million 
for point focus systems) and $\$ 22$ million for the Advanced Technology Program.

2. Market identification. - Market identification activities are centered around characterization of markets of early opportunity (before 1985), nearterm (1985-1990), and long-term (1990-2000+) markets for the various concentrator systems. Specific applications' requirements will reward the capabilities of certain concentrators and penalize the limitations of others. Temperature, size, and geography are important market-related dimensions. Achievable concentration ratios impose practical limits on the deliverable temperature, inherent concentrator system modularities span four orders of magnitude ( $10 \mathrm{kWe}$ to $100 \mathrm{MWe}$ ), and the effects of latitude and atmosphere make certain concepts more attractive than others.

At present, it appears likely that each of the major concentrator systems options will find sectors of the energy market in which its unique technical characteristics afford it a significant competitive advantage relative to others. In the central receiver area, a major assessment of utility repowering as an early opportunity for market development and industrialization was recently completed at the Solar Energy Research Institute (SERI). Repowering involves the construction of a solar thermal steam supply system adjacent to an existing fossil-fired power plant or industrial boiler to reduce or eliminate requirements for oil or natural gas consumption. Based on analysis of utility requirements by Westinghouse Electric, SERI concluded that the utility repowering market over the next decade presents an opportunity for early sales of central receiver systems, leading to accelerated industrialization. Solar enhanced oil recovery applications have been tentatively identified as a comparable early opportunity for the embryonic parabolic trough industry, with 15-50 billion barrels of otherwise environmentally-constrained heavy oil resources in the sun-belt at stake. Similarly, well over a hundred small towns have expressed interest in parabolic dish concentrators for small community electric applications.

These applications require heat at temperatures above $150^{\circ} \mathrm{C}$ and pave the way to bulk utility and industrial energy markets. In parallel, concentrating collectors will also compete strongly in low temperature - under $150^{\circ} \mathrm{C}\left(300^{\circ} \mathrm{F}\right)$ - applications where non-concentrating flat plate collectors are now being introduced. Moreover, beyond the year 2000, very high temperature concentrator technology may be applied to the production of transportable fuels for the balance of our national energy requirement.

3. Central receiver program. - The objective of this program is to establish the technical readiness of cost-competitive central receiver systems for initial applications in the mid 1980's. The central receiver concept involves a field of two-axis tracking mirrors (heliostats) focusing sunlight on a common boiler or receiver. The concept was recognized early as being particularly advantageous for large-scale high temperature systems, and initial efforts were directed towards bulk electric power applications. Recent studies have identified the central receiver concept as being potentially cost effective for smaller systems as well. Various applications are being evaluated, including cogeneration (production of electricity and heat) and industrial process heat over a broad range of temperatures.

The Central Receiver Program will be implemented to take full advantage of the Power Plant and Industrial Fuel Use Act of 1978 (one of the five bills comprising the National Energy Act). This legislation prohibits use of oil or natural gas in new electric utility generation facilites or in new industrial boilers with a fuel heat input rate of $100\left(10^{9}\right) \mathrm{J}(100$ million Btu's) per hour or greater, unless exemption is granted by DOE. Similarly, the Act encourages, and in some cases requires, existing oil and natural gas facilities to convert to coal or an alternate fuel. These provisions open the door to action by DOE to encourage the construction of new solar thermal facilities (e.g., solar stand alone plants), or to retrofit existing plants (repowering) to reduce utility and industrial dependence on imported oil and natural gas.

The Central Receiver Program includes two major activities, the first dealing with system development and including major applications experiments and the second with the development and qualifications testing of heliostats and receivers. The Systems/ Applications Subprogram is managed by the DOE San Francisco Operations Office (SAN).

A key milestone in the Central Receiver Systems/ Applications Subprogram is the operation of the $10 \mathrm{MWe}$ central receiver utility pilot plant near Barstow, California, in late 1981. While considerably smaller than most present day power plants, the pilot plant will simulate performance of such systems under conditions of utility operation. It will also provide collector production experience applicable to nearterm uses for central receivers, and initial cost data related to operation and maintenance. The preliminary design for the project has been completed and the heliostat supplier (Martin Marietta) has been selected.

Emphasis in related system development efforts and heliostat and receiver testing is on designs for the repowering (see Fig. 1) of existing electric power plants and industrial process heat facilities where the solar portion of the system serves as the energy source during sunlight periods and other times if thermal storage is available.

Thirteen utilities and industrial users have teamed with central receiver industrial firms to develop sitespecific repowering systems conceptual designs. Scheduled for completion in mid-1980, these efforts will provide a basis for selection and initiation of the preliminary design phase of applications experiments in FY 81. 


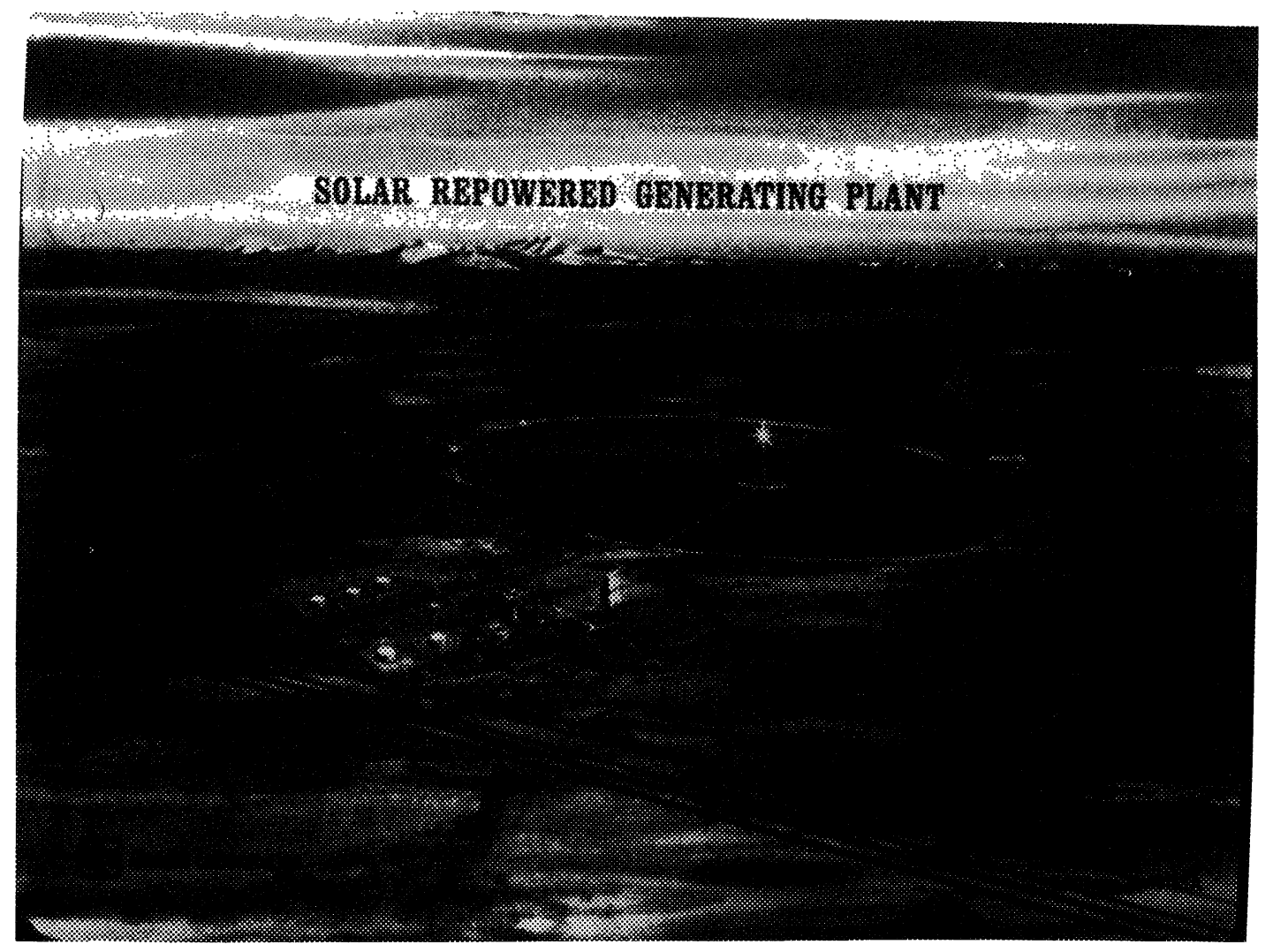

Fig. 1. - Central receiver utility repowering.

Secondary emphasis has been placed on stand-alone storage-coupled systems that utilities and industries may install when additional plant capacity is needed. Although stand-alone systems are not expected to be the earliest application for larger scale central receivers, they will displace much larger amounts of oil and natural gas than the initial repowering applications. Consequently, they are expected to become the most significant central receiver configuration once the initial fuel saving installations have created the opportunities for industry to implement low cost receiver designs and to tool up for large scale production of heliostats.

In addition to development of designs for largescale applications, a $500 \mathrm{kWe}$ sodium-cooled central receiver project is being funded by nine International Energy Agency member countries, including the U.S. This system, now under construction in Spain, will be completed in 1981 and operated for 2 years thereafter to evaluate the design features chosen for this project.

Project definition activities for small-scale cogeneration experiments are also underway. In FY 1981 conceptual designs for a cogeneration experiment will be initiated to obtain engineering data for plants designed to optimize the simultaneous use of solar energy for process heat (or space heating and cooling) and electric power.

Development of low-cost heliostats and advanced receiver subsystems is also being heavily emphasized, as the key to a successful pre-commercialization effort. Sandia Laboratories at Livermore, California is managing this element of the Central Receiver Program.

First generation heliostat efforts are focused on testing of three designs, including the prototypes of two designs proposed for use in the 10 MW Pilot Plant. Second-generation activities center on the construction in FY 1980 of five mass-producible heliostat prototypes. In addition, third-generation heliostat development of lightweight plastic structures will be initiated in FY 1981. Research on long-lived plastics will be undertaken in support of the plastic heliostat program.

The Central Receiver Test Facility (CRTF) (see Fig. 2) in Albuquerque is used for both heliostat testing as well as receiver development and testing activities.

In the receiver subsystem area, advanced watersteam, high temperature air, molten salt, and liquid metal central receiver designs are now under development. Small prototype molten salt and liquid metal receivers are to be tested at CRTF in FY 1980 and FY 1981. As these designs mature, additional receiver prototypes, including water/steam receivers for industrial heat, will be constructed and tested at the CRTF.

4. Distributed receiver program. - The Distributed Receiver Program encompasses component, subsystem, and system development and engineering expe- 


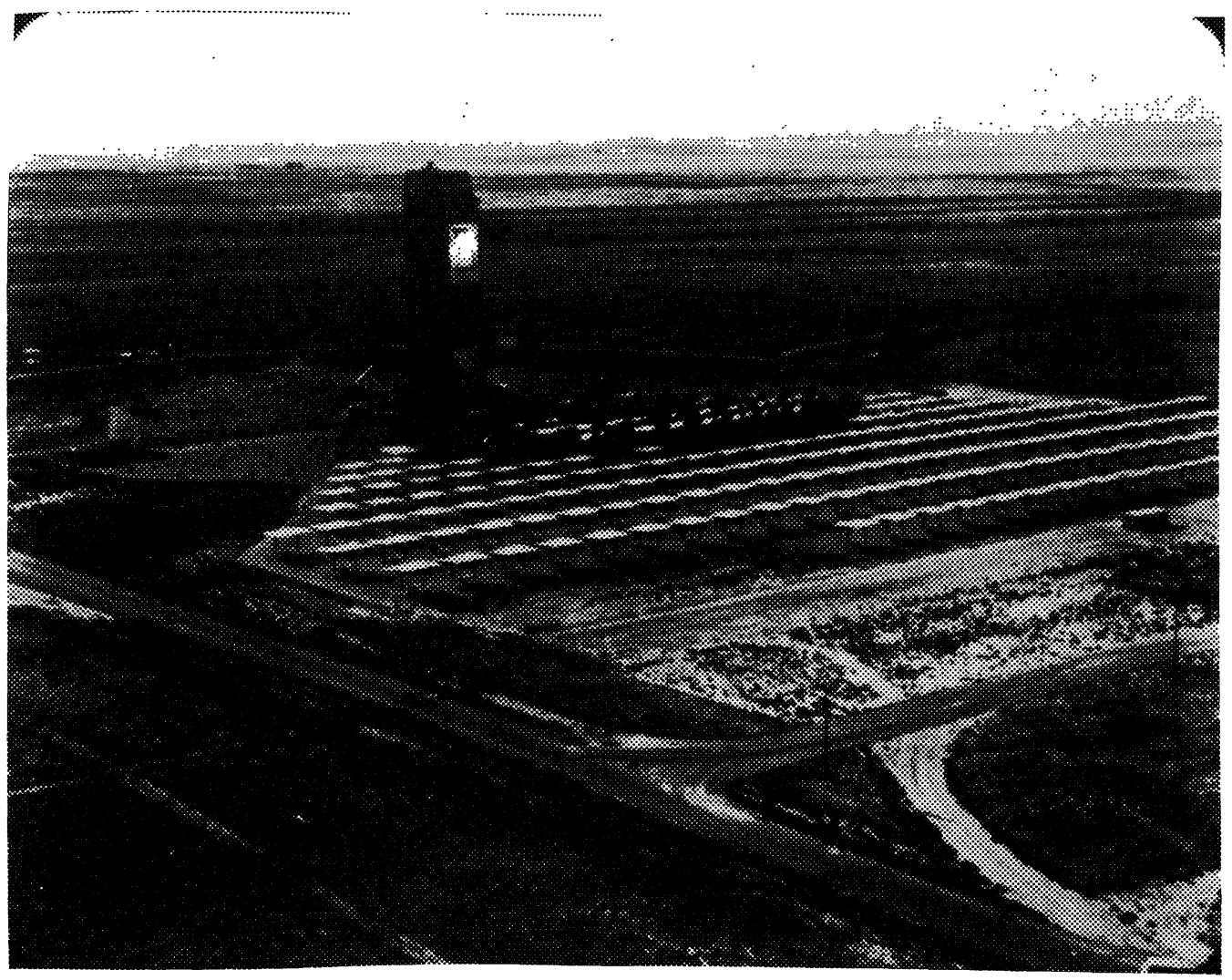

Fig. 2. - Receiver testing at CRTF.

riment activities in support of those concentrating collector technologies in which the receivers and concentrators are part of the same module.

The subprograms within the Distributed Receiver Program include line-focusing and point-focusing systems/subsystems. Sandia Laboratories at Albuquerque is responsible for line-focusing technology development. The DOE Albuquerque Operations Office (ALO) is project manager for most related applications experiments within the line focus area. In the Point Focusing Subprogram, the Jet Propulsion Laboratory is the decentralized manager of development efforts.

LINE FOCUSING SYSTEMS. - The two primary technologies under development in the Line Focus Subprogram are parabolic troughs and hemispherical bowls. Parabolic trough systems activities are focused on two projects : the $25 \mathrm{hp}$ shallow well irrigation pumping experiment at Willard, New Mexico (operational since 1977) and the recently dedicated $150 \mathrm{kWe}$ deep well pumping experiment at Coolidge, Arizona (see Fig. 3). Under study at Sandia Laboratory (Albuquerque) is the use of medium temperature concentrators - above $315^{\circ} \mathrm{C}\left(600^{\circ} \mathrm{F}\right)$ - for industrial process heat applications such as enhanced oil recovery. Although several small lower temperature industrial heat demonstrations employing trough collectors have been deployed, there is a continuing need to verify performance, reliability, and durability of improved, mass-producible parabolic trough systems in actual industrial applications. The IEAsponsored effort in Spain also provides for construction of a $500 \mathrm{kWe}$ distributed receiver system at the same site and on the same schedule as the sodium receiver/steam Rankine system mentioned above.

Subsystem/component development efforts include the development and demonstration of a massproducible parabolic trough design satisfying $60 \%$ collection efficiency targets at the Mid-temperature Solar System Test Facility (MSSTF) (see Fig. 4) in Albuquerque. Related efforts are underway, including studies of sheet metal, sandwich, and sheet-molded concentrator structures.

The fixed hemispherical bowl (moving receiver) concept is also under investigation within the Line Focus Subprogram. Installation of a twenty meter (65-foot) bowl - shown under construction in figure 5 - is completed and is now undergoing checkout, with testing to be initiated shortly. Based on results of the testing, a decision will be made as to whether or not to proceed with a $5 \mathrm{MWe}$ electric pilot plant for the town of Crosbyton, Texas. Potential applications for the bowl include electric irrigation and small community markets.

PoINT FOCUS SUBPROGRAM. - Two-axis tracking parabolic dishes and other point-focusing distributed receiver concepts offer high optical performance, high temperature capability and land use advantages 


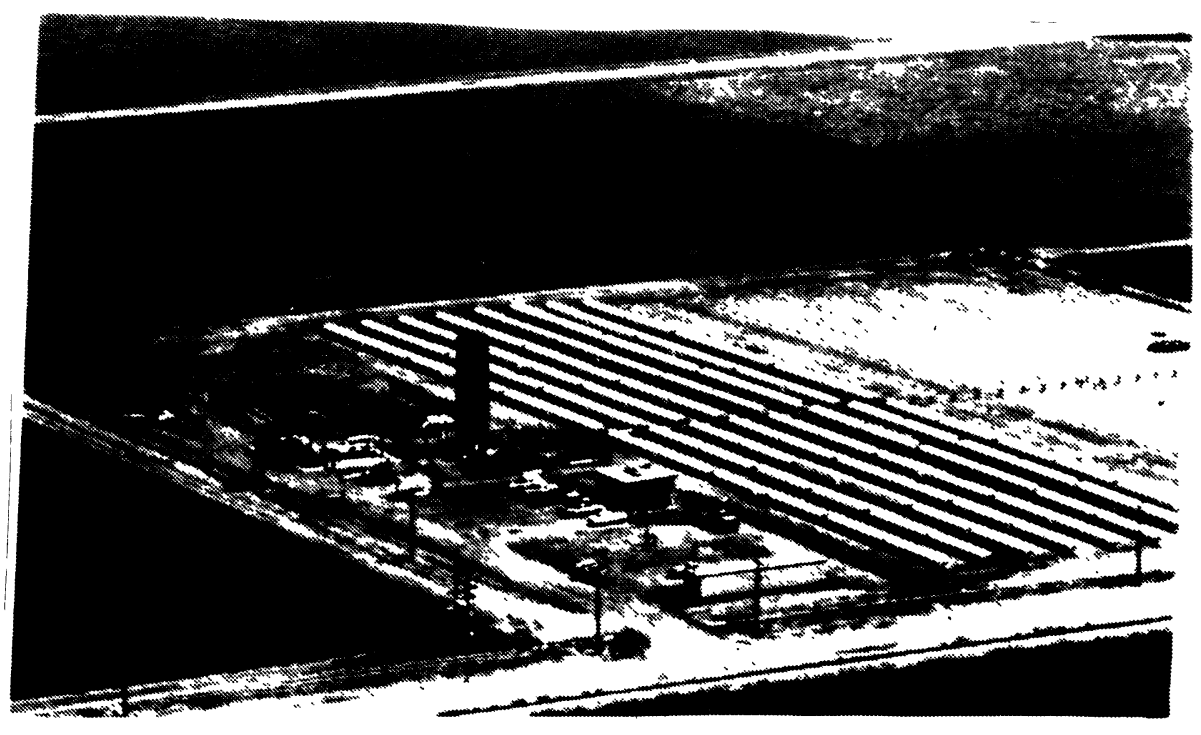

Fig. 3. - Trough irrigation pumping at Coolidge.

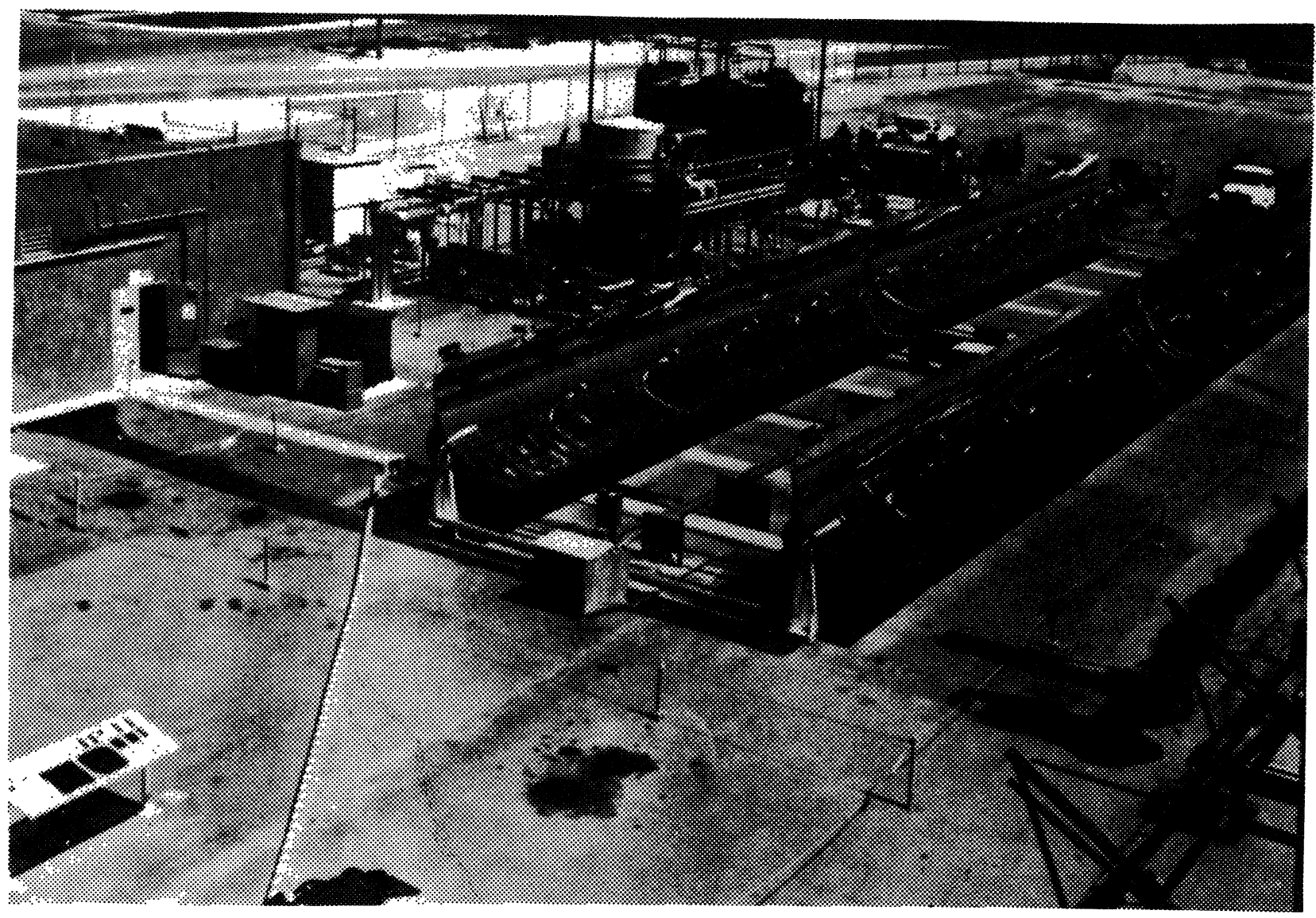

Fig. 4. - Trough test at MSSTF.

as well as a high degree of modularity. Near-term applications for dishes include small community electric systems and remote applications. Ultimate markets may include industrial total energy applications and bulk electric energy supply.

Dish systems-level activity includes a $400 \mathrm{kWe}$ intermediate temperature $-400^{\circ} \mathrm{C}\left(750^{\circ} \mathrm{F}\right)-$ total energy experiment at a knitwear factory in Shenandoah, Georgia. This system will provide electricity as well as process steam, heating and cooling to the plant. Initial checkout of this facility will begin in September, 1981. A second project involving higher 

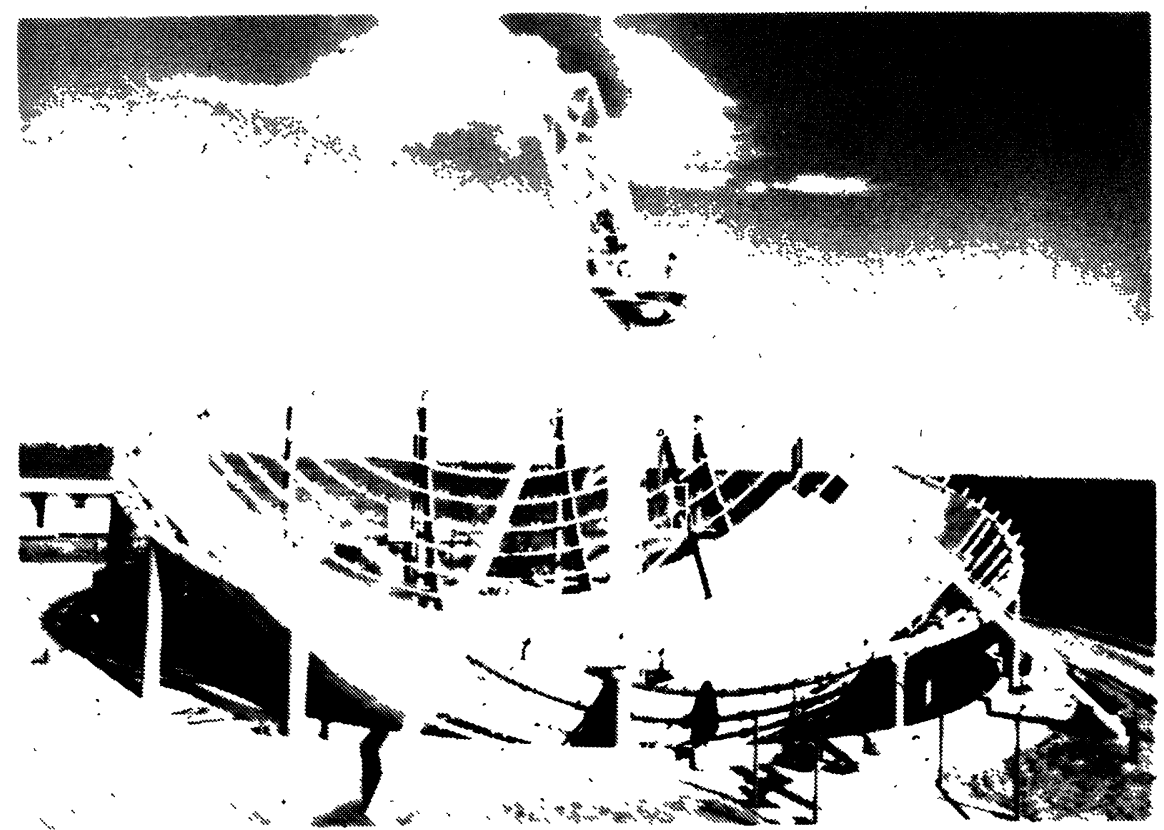

Fig. 5. - Hemispherical bowl construction.

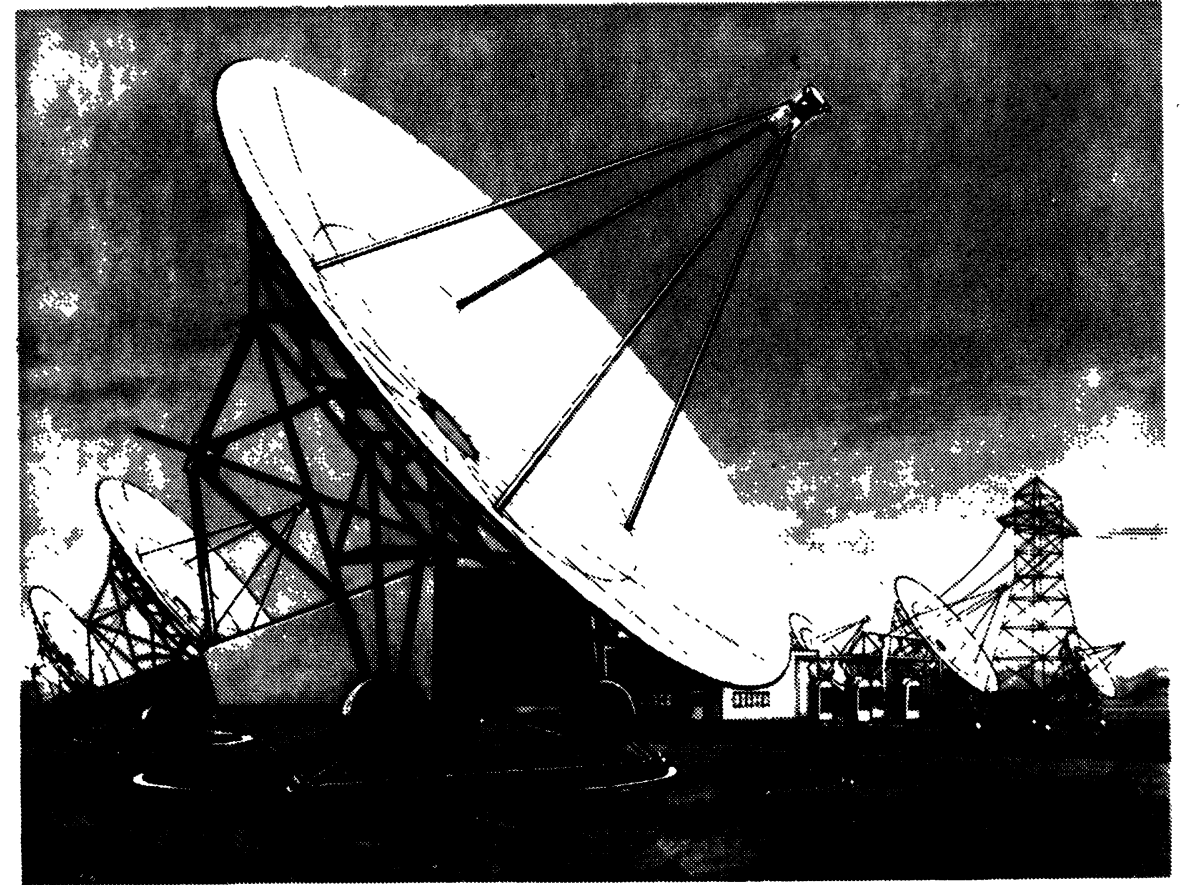

Fig. 6. Dish small community application.

temperature - $540^{\circ} \mathrm{C}\left(1000^{\circ} \mathrm{F}\right)$ - collectors is a 1 MWe experiment (see Fig. 6) for which the site solicitation has already been released. Well over a hundred small towns have expressed interest in hosting this experimental project, which is planned for operation in 1983. The system to be used is a series of parabolic dishes with heat engines mounted at the focal point. Activities in FY 1980 will concentrate on site selection and design and development of key subsystems, with subsystem testing to be initiated in FY 1981.

Experiments in the planning stage include a $100 \mathrm{kWe}$ modúlar military power experiment (EE 2a) cofunded with the DOD/Navy. The Navy has already selected the site, and an RFP to engage the power plant system supplier has been issued. A second RFP will be issued 
in late FY 1980 to initiate a second experiment (EE 2b) also of about $100 \mathrm{kWe}$ for the near-term isolated load application area. This project would get underway in FY 1981.

Dish subsystem/component efforts include development of first generation concentrators, Brayton cycle heat engines - up to $815^{\circ} \mathrm{C}\left(1500^{\circ} \mathrm{F}\right)$ - and receivers, including development of prototype concentrator modules for the first applications experiments. To support the development of dish-mounted heat engine/generator and heat production systems, the Parabolic Dish Test Site (PDTS), see figure 7, is in initial use and under further construction at Edwards Test Station near Victorville, California. A commer- cially available dish module has been purchased and is being tested and two test bed concentrators have been installed and are undergoing a thorough checkout before use. In FY 1980 a steam receiver, an air receiver, and a combined air receiver/Stirling heat engine will be tested. In FY'1981, the first generation low cost dish concentrator will be installed and checked out and an open cycle Brayton heat engine/air receiver will be mounted on the concentrator and tested.

5. Advanced technology program. - The Advanced Technology Program objectives are : (1) to identify new components and subsystems for various solar thermal applications and to verify their technical

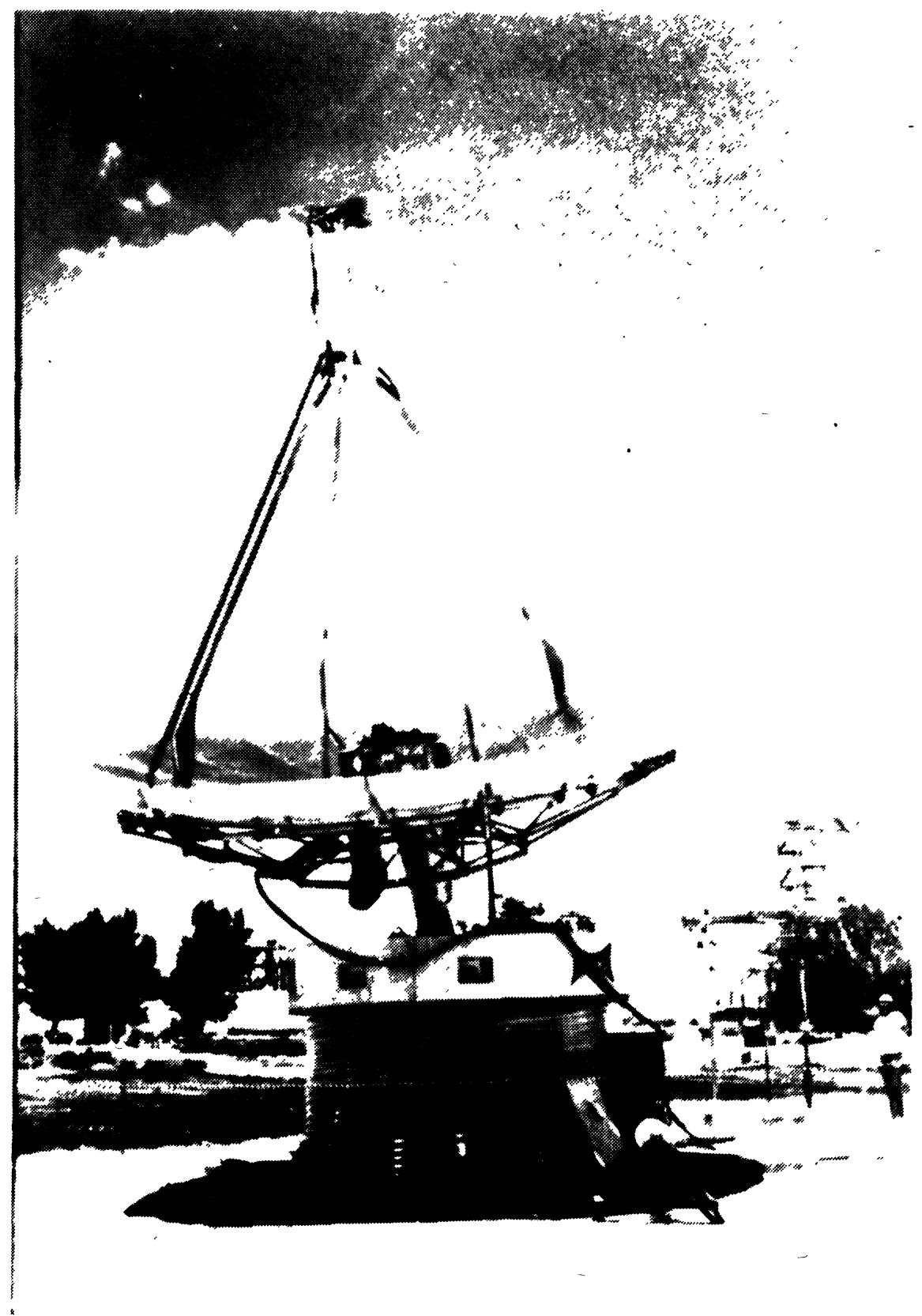

Fig. 7. - Dish test at PDTS. 
feasibility, (2) to develop more durable, lower-cost materials for central and distributed receiver solar thermal systems, (3) to identify and investigate new applications and processes, and (4) to provide the generic data and information base necessary for the commercialization and market acceptance of solar thermal systems. SERI has been designated the decentralized manager for the advanced components/ subsystems, materials, and supporting program elements of the Advanced Technology Program.

In the advanced component/subsystem development subprogram, work is underway on advanced receivers, thermal storage, and transport subsystems. In advanced receiver research, emphasis is on central receiver and dish systems and evaluation of materials-handling concepts for receiver/reactors.

Advanced receiver development includes conceptual design studies of high temperature, $1100-1650{ }^{\circ} \mathrm{C}$ (2 000-3 000 $\left.{ }^{\circ} \mathrm{F}\right)$, ceramic air receivers, and development and testing of advanced Brayton metal receivers - $815^{\circ} \mathrm{C}\left(1500^{\circ} \mathrm{F}\right)$ - and advanced Rankine metal receivers - 600-700 ${ }^{\circ} \mathrm{C}$ (1 100-1 300 $\left.{ }^{\circ} \mathrm{F}\right)$. Receivers/ reactors under investigation for fuels and chemicals processes include a ceramic $\left(\mathrm{SO}_{3}\right)$ counterflow high temperature receiver and a thermosyphon (sodiumcooled) receiver [3].

During FY 1979, a plan for the coordinated development of thermal storage subsystems for solar thermal systems was established. During FY 1980, the development of second generation storage subsystems to meet needs of near-term applications will be initiated. Attractive storage concepts will be identified and conceptual designs initiated. Subsequent work will include detailed design and construction of experimental storage subsystems applicable to such solar thermal systems as steam/water and molten salt central receivers, mid-temperature distributed receivers typified by the Shenandoah, Georgia total energy system and high temperature point focus systems.

Energy transport requirements for future solar thermal systems will be reviewed during FY 1980. Thermal-transport subsystems have been identified as requiring additional $\mathrm{R}+\mathrm{D}$ if larger, high-temperature solar thermal IPH systems, based on hightemperature distributed receivers are to become economically viable. During FY 1981, activities will be initiated to identify candidate transport subsystems and to start their development. High temperature concepts of interest include molten salts, high temperature gas and, in the long term, thermochemical transport subsystems.

In the materials subprogram, emphasis is on identifying low cost silver/glass mirror components, evaluation of thin glass for reflectors, low-cost stable polymers for transmitting material applications, establishing the temperature stability of black chrome and black cobalt selective absorbers, evaluation of support structures for concentrators, and testing of ceramics for high temperature receivers.

During FY 1980, advanced systems development activities will be aimed at development of a third generation parabolic dish electric power system and identification of solar-driven fuels production processes.

A parabolic dish-Stirling engine electric power system was selected in FY 1978-79 as an advanced concept offering potentially significant cost advantages over first generation designs using other engine technologies. During late FY 1979, contracts were issued for the development of key subsystems, including the receiver/engine and a segment or "gore" of a lowcost high performance dish. During FY 1980, the first receiver-engine subsystem utilizing a United Stirling P-40 engine will be tested. Upgrading and additional testing of this subsystem will be conducted in FY 1981. Moreover, an additional subsystem utilizing a heat receiver coupled to a Phillips I-98 Stirling engine will be fabricated during FY 1981. These efforts will establish the technical feasibility of the dish-Stirling system concept.

In the fuels and chemicals sector, tests were performed in FY 1978 by Lawrence Livermore Laboratory scientists at the White Sands Missile Range that demonstrated the technical feasibility of using high temperature solar receivers to assist coal gasification. Experiments are planned for FY 1980 to demonstrate the feasibility of solar retorting of shale oil, solar pyrolysis of biomass, and solar production of calcium carbide. During FY 1980, a solicitation will be issued to select an industrial program manager familiar with fuels/chemicals processing to assist in the initial phases of the development of necessary thermochemical processes. During FY 1981, it is expected that conceptual designs of candidate systems which utilize solar heat will be conducted.

The program is also concerned with technical information dissemination. Coordination of related efforts is now centered at SERI, under the direction of Ms. Margaret Cotton. Other generic concerns, including reliability and standards, environmental assessments, and solar radiation resource assessment, are also under investigation.

6. Conclusions. - Solar high temperature concentrator systems have broad market potential and adapt well to existing industrial facilities and power plants. Feasibility has been established and systems will be ready for commercialization by the early 1980 's. Industrial process heat comprises a major near-term market which requires solar/fossil hybrid systems.

Central receiver technology is well developed. The $10 \mathrm{MW}$ pilot plant near Barstow, California is on track, scheduled for completion in 1981. Follow-up projects establishing the connection between pilot plants and initial utility and industrial repowering 
markets are underway. These projects have received enthusiastic support from the utility industry and potential commercial heliostat suppliers.

In the distributed receiver area, the nucleus of a trough collector industry has emerged. Five companies are in business, others are considering production, and the market is encouraging, given present levels of production. The 20 -meter (65-foot) test module, now under construction at Crosbyton, Texas, represents a major engineering hurdle for hemispherical bowl technology. Parabolic dish technology is developing rapidly after a late start. The first major installation involving dishes will be located at Shenandoah, Georgia.

Advanced development efforts are focusing on :

- expanding and accelerating market penetration by improving materials and component performance ;
- providing storage technology that enhances capacity factor and fuel displacement potential, and

- providing higher temperature technology for additional IPH applications and, ultimately, for production of transportable fuels.

As mass-producible designs are defined and tested and production studies completed, earlier favorable cost projections are holding firm and gaining credibility. Pilot plant designs, if built today, would cost four times the program goals. Improved designs, high-volume concentrator production, and systemslevel experience will fill the gap. Experience is also the key to investment decisions that will initiate commercialization. Operating experience with real applications beyond initial pilot plants will be necessary to establish user confidence relative to reliability and durability and supplier confidence relative to pricing.

\section{References}

[1] Yellott, J. I., "Power from Solar Energy ", Transactions of the ASME, August 1957

[2] Meinel, A. and Meinel, M., Applied Solar Energy : An Introduction (Addison-Wesley Publishing Company) June, 1977.
[3] Kudirka, A. A., "Advanced Receiver Technology ", Fourth Semi-Annual Conference Advanced Solar Thermal Technology Program : Meeting Abstracts, at Phœnix, Arizona, December 11-13, 1979. 